\title{
Variegated Arecanut (Areca Catechu L.)
}

NAGARAJA N R ( $\nabla$ naga_gene@yahoo.com)

CENTRAL PLANTATION CROPS RESEARCH INSTITUTE https://orcid.org/0000-0003-1246-0859

Arivalagan $\mathrm{M}$

ICAR-IIHR, Bengaluru

Chowdappa P

ICAR-CPCRI, Kasaragod

\section{Research Article}

Keywords: Areca catechu L., Variegated arecanut, Mangala, South Kanara Local, Photosynthesis, Biochemical constituents

Posted Date: June 2nd, 2021

DOl: https://doi.org/10.21203/rs.3.rs-531794/v1

License: (c) (1) This work is licensed under a Creative Commons Attribution 4.0 International License. Read Full License 


\section{Abstract}

Variegations in ornamental crops are not uncommon however, reports of variegations in Areca catechu L.-an economically important plantation crop have not been made yet. In the present study we have identified and characterized the palms of Mangala and South Kanara Local populations that showed variegation trait. These variant palms have variegated green and yellow stripes on nuts, leaves, leaf sheath and greener portion of the stem. Besides morphological differences, kernels also showed variations. Significant differences in the physiological and biochemical parameters of these off-types were recorded. Physiological parameters like photosynthetic rate, stomatal conductance, transpiration rate, stomatal resistance and chlorophyll index were recorded from the greener portion of variegated leaves, yellow regions of the variegated leaves and control leaves (wild type leaves). The photosynthetic rate of greener portion of variegated leaves did not differ significantly from the wild type leaves in both Mangala and S.K. Local varieties. But in both the varieties significant differences were observed between greener portion of variegated leaves and wild type leaves with yellow regions of the variegated leaves. Similarly, in both the varieties stomatal conductance of green region of variegated leaves and normal leaves are higher than yellow regions of the variegated leaves, so is the transpiration rate. Greener portion of variegated leaves and the normal leaves showed higher values for transpiration than yellow regions of the variegated leaves in both the varieties. Yellow regions of the variegated leaves showed low transpiration rate in Mangala and S.K. Local varieties. Expectedly, stomatal resistance was low in green region of variegated leaves and normal leaves compared to yellow regions. Yellow regions of the variegated leaves showed very low chlorophyll index compared to green region of variegated leaves and normal leaves in both the varieties. Biochemical constituents like total sugar, total phenolics, non-tannin phenolics and antioxidant potential in terms of reducing power using CUPRAC and FRAP methods were analysed along with moisture content in both immature and ripened arecanut of both normal and variegated types of Mangala and South Kanara Local varieties. The biochemical analysis results indicated wide variation between normal and variegated types for all the biochemical constituents studied. The genetic, biochemical and physiological significance of these variegations are discussed in this paper.

\section{Introduction}

Arecanut (Areca catechu L.) or betelnut is an extensively cultivated tropical palm, the nuts of which are chewed as a mild stimulant. The palm grows to a height of about 12-30 m. The stem is straight with smooth green upper portion and annulate. The crown is compact with an average production of eight to nine pinnate leaves per year which are partly free and partly fused. The basal region of the leaves expands into smooth green amplexicaul sheath, which completely encircles the stem so as to protect the developing inflorescence until a few days prior to opening. Leaflets are thin and often confluent with several midribs, which attached to the rachis in a vertical line. The anatomy of the leaflet shows an upper epidermis consisting of a single layer of cells with a thick cuticle, palisade parenchyma, vascular bundles, spongy parenchyma and lower epidermis. The immature fruits are smooth surfaced having uniform green colour which turn to orange red/ scarlet when ripe. The endosperm of the seed is reddish brown with dark wavy lines giving it a marbled appearance. The exocarp of the fruit consists of the epidermis covered by a cuticle and parenchymatous cells inter-mixed with stray collenchyma and separate strands of thin fibres. The upper 10-12 layers of parenchyma contain chloroplasts (Bavappa, 1966).

Variegation is the presence of discrete markings of different colours on an organ or an organism (Marcotrigiano, 1997). In plants it is frequently manifested as stripes, blotches, or streaks of white, cream, yellow, or other colors. It is also observed by difference in colour between leaf/petal margins and the mid region. Variegation includes pattern and non-pattern types. In the former, predictable, regular and repeated pattern between the leaves or petals are seen, whereas in the later the extent of colour is variable and unpredictable (Marcotrigiano, 1997). Kirk and Tilney-Bassett (1978) categorized the variegation in plants as either cell lineage or non-cell lineage types. Cell lineage variegation generally occurs in genetic mosaics, whereas, in non-cell lineage variegation all cells have the same genotype but the genes responsible for the synthesis or destruction of pigments are expressed only in some of the cells. Cell lineage variegation is usually expressed in monocots by striped or striated patterns. Some of the most common variegations have green and white (or yellow) sectors in normallygreen tissues and organs of the plant. Whereas cells in the green sectors typically contain normal-appearing chloroplasts, cells in the white (or yellow) are deficient in chlorophyll mainly due to inhibition of thylakoid development (Tsai et al., 2017).

Many reports are available on variegation in plants especially in ornamentals. But to our knowledge this is the first report of variegation in arecanut. In the present study, we have identified and characterized the variegated arecanut among Mangala and South Kanara Local populations.

\section{Materials And Methods Plant materials}

Thirty-seven variegated seed nuts collected from variegated tree of South Kanara Local variety from farmer garden at Gardady, Belthangady Tk., Dakshina Kannada Dt., Karnataka were used for sowing. Normal and variegated tree leaves of both Mangala and South Kanara Local genotypes were used for measuring physiological parameters. Immature and ripe nuts of both normal and variegated types of Mangala and South Kanara Local varieties were used for biochemical analysis.

\section{Physiological parameters}

Leaf gas exchange of the normal and variegated arecanut leaves of both Mangala and South Kanara Local genotypes was measured using Li-6200 portable photosynthesis equipment (Licor Inc. Lincoln, Ne USA). The system allows for the measurement of various parameters such as net photosynthesis (Pn), stomatal conductance (gs), and transpiration rate (E). Fully opened top most leaf was used for the measurement of above cited parameters under the conditions of full sunlight at 10 am and photon flux density of $1200 \mu \mathrm{mol} \mathrm{m} \mathrm{m}^{-2} \mathrm{~s}^{-1}$. Specifically, in the variegated leaves photosynthetic parameters were measured in both the green and yellow regions. Similarly, stomatal resistance (Rs) was measured using the AP4 porometer (Delta-T Devices UK). Chlorophyll index of the leaves were obtained using leaf chlorophyll meter (at LEAF + USA). The optical density at two wavelengths (660nm and $940 \mathrm{~nm}$ ) was measured to estimate the relative chlorophyll content. Measurements were made at a photon flux density of 800 to $1200 \mu \mathrm{mol} \mathrm{m}^{-2} \mathrm{~s}^{-1}$.

Page 2/9 


\section{Sample preparation for biochemical analysis}

Three lots, containing 10 nuts each of immature and ripe nuts of both normal and variegated nuts of Mangala and South Kanara Local varieties were collected from the farmer's gardens at Dakshina Kannada district of Karnataka. Fruits were carefully dehusked and kernels were carefully removed. The kernels were dried in mechanical tray dryer at $50^{\circ} \mathrm{C}$ and defatted using Soxhlet apparatus for $4 \mathrm{hr}$ using petroleum ether (boiling point $60-80^{\circ} \mathrm{C}$ ). The defatted kernels were finely powdered using ball mill (Mixer Mill MM400, RETSCH GmbH, Germany) and screened through 200 mesh to get uniform particle size, which was used for biochemical constituents analysis using different solvent systems.

\section{Determination of total sugars, total phenolics and antioxidant potential}

Total sugar in the normal and variegated arecanut was estimated by phenol-sulphuric acid method (DuBois et al., 1956). Total phenolic content (TPC) in the extract was determined by Folin-Ciocalteu (FC) assay as described by Singleton et al. (1999) using gallic acid as a standard. Total phenol content was expressed as g gallic acid equivalent (GAE), per $100 \mathrm{~g}$ dry weight of arecanut. Similarly, non-tannin phenolics were also measured using Folin-Ciocalteu (FC) assay after removal of tannins using polyvinylpolypyrollidine. The antioxidant potential of arecanut samples was determined based on reducing power principle using FRAP and CUPRAC assays. The FRAP (Ferric Reducing Antioxidant Power) assay was done according to Benzie and Strain (1996) and CUPRAC (Cupric ion reducing antioxidant capacity) of the extract was determined according to the method of Apak et al. (2004). In both the methods, Trolox served as a positive control and results were expressed in $\mathrm{mM} \mathrm{TE} / 100 \mathrm{~g}$ dry arecanut sample.

\section{Results And Discussion}

\section{Variegated arecanut palms and morphology}

The arecanut palms exhibiting variegation trait at the farmers' gardens of Dakshina Kannada district of Karnataka was seen among the varieties Mangala (early flowering, semi tall, improved high yielding popular variety released by ICAR-CPCRI) and South Kanara Local (popular local variety). These variant palms are like normal trees but, characterized with variegated green and yellow stripes on nuts, leaves, leaf sheath and greener portion of the stem. Kernel of the variegated arecanut of Mangala population was whitish (cream) in colour as against the normal red kernel colour. However, the variegated arecanut of South Kanara Local population are characterised with strong red coloured kernel in comparison to the non-variegated type (Figure 1 and 2). Out of thirty-seven seed nuts collected from variegated tree of South Kanara Local and sown in nursery at ICAR-CPCRI, Regional Station, Vittal, only two progeny seedlings showed variegation trait. Kher (1961) in his studies on variegated mango mentioned that, if the variegation is due to any pathogen, pathogen would have multiplied and invaded new tissues effecting some changes in the entire pattern and the fact that twelve out of the fifteen mango seedlings showed the same abnormality (variegation) also goes in favour of attaching a genetic origin for the variegation.

Variegated and normal/ wild type trees of both the varieties were also characterized for their morphological traits like Plant Ht. (m), Stem Ht. (m), Crown Length $(\mathrm{m})$, Stem Girth $(\mathrm{cm})$, Internodal Length $(\mathrm{cm})$, No. of Leaves, Leaf Length (cm), Leaf Breadth (cm), No. of Leaflets (Left), No. of Leaflets (Right), No. of Midribs (Left), No. of Midribs (Right), Lower Leaflet Length (Left) (cm), Lower Leaflet Length (Right) (cm), Middle Leaflet Length (Left) (cm) and Middle Leaflet Length (Right) $(\mathrm{cm})$ and the details are given in Table 1. Variegated tree of Mangala variety showed higher values for the morphological traits like plant ht. (11.02 m), stem ht. (9.17 m), no. of leaflets (R) (41), lower leaflet length (Right) $(64 \mathrm{~cm})$ compared to wild type tree, plant ht. (9.09 m), stem ht. (7.13 m), no. of leaflets (R) (38), lower leaflet length (Right) $(56 \mathrm{~cm})$. Wild type tree of the same variety recorded higher values for other morphological traits like crown length $(1.96 \mathrm{~m})$, stem girth $(50 \mathrm{~cm})$, internodal length $(14.15 \mathrm{~cm})$, no. of leaves $(11)$, leaf length $(160 \mathrm{~cm})$, leaf breadth $(180 \mathrm{~cm})$, no. of leaflets (Left) $(43)$, no. of midribs (Left) (69), no. of midribs (Right) (67), lower leaflet length (Left) (78 cm), middle leaflet length (Left) (84 cm) and middle leaflet length (Right) (89 cm) than variegated tree, crown length $(1.85 \mathrm{~m})$, stem girth $(48 \mathrm{~cm})$, internodal length $(12.9 \mathrm{~cm})$, no. of leaves $(10)$, leaf length $(157 \mathrm{~cm})$, leaf breadth $(162 \mathrm{~cm})$, no. of leaflets (Left) (35), no. of midribs (Left) (63), no. of midribs (Right) (61), lower leaflet length (Left) (62 cm), middle leaflet length (Left) (80 cm) and middle leaflet length (Right) $(74 \mathrm{~cm})$.

The variegated tree of S.K. Local variety reorded higher values for morphological traits like crown length (1.02 m), no. of leaves (11), leaf length (195 cm) compared to wild type tree, crown length $(0.91 \mathrm{~m})$, no. of leaves $(10)$, leaf length $(140 \mathrm{~cm})$. Wild type tree of S.K. Local variety showed higher values for morphological traits like plant ht. $(11.67 \mathrm{~m})$, stem ht. $(10.76 \mathrm{~m})$, stem girth $(54 \mathrm{~cm})$, internodal length $(14.19 \mathrm{~cm})$, leaf breadth $(155 \mathrm{~cm})$, no. of leaflets $($ Left) (43), no. of leaflets (Right) (44), no. of midribs (Left) (67), lower leaflet length (Left) (78 cm), lower leaflet length (Right) (76 cm), middle leaflet length (Left) (81 $\mathrm{cm})$ and middle leaflet length (Right) $(73 \mathrm{~cm})$ than variegated tree, plant ht. $(9.42 \mathrm{~m})$, stem ht. $(8.40 \mathrm{~m})$, stem girth $(44 \mathrm{~cm})$, internodal length $(10.83 \mathrm{~cm})$, leaf breadth (145 cm), no. of leaflets (Left) (37), no. of leaflets (Right) (38), no. of midribs (Left) (65), lower leaflet length (Left) (68 cm), lower leaflet length (Right) $(68 \mathrm{~cm})$, middle leaflet length (Left) $(75 \mathrm{~cm})$ and middle leaflet length (Right) $(70 \mathrm{~cm})$. Both variegated and normal trees recorded same no. of midribs (Right) $(68)$.

\section{Effect of variegations on photosynthetic parameters}

Physiological parameters like photosynthetic rate, stomatal conductance, transpiration rate, stomatal resistance and chlorophyll index were recorded from the greener regions of variegated leaves, yellow regions of the variegated leaves and control leaves (wild type leaves) and the results are given in Table 2. The photosynthetic rate of greener portion of variegated leaves did not differ significantly from the wild type leaves in both Mangala and S.K. Local varieties. The photosynthetic rate of greener portion of variegated leaves and wild type leaves of Mangala variety is $4.4104 \mu \mathrm{mole} \mathrm{m}^{-2} \mathrm{~s}^{-1}$ and $3.4348 \mu \mathrm{mole} \mathrm{m}^{-2} \mathrm{~s}^{-1}$ respectively and in S.K. Local variety the values were $3.7080 \mu$ mole m$^{-2} \mathrm{~s}^{-1}$ and $3.8569 \mu \mathrm{mole} \mathrm{m}^{-2} \mathrm{~s}^{-1}$ respectively. But in both the varieties significant differences were observed between greener portion of variegated leaves and wild type leaves with yellow regions of the variegated leaves. Photosynthetic rate of yellow regions of the variegated leaves of Mangala variety is $1.1966 \mu$ mole $\mathrm{m}^{-2} \mathrm{~s}^{-1}$ and that of S.K. Local variety is $1.7332 \mu \mathrm{mole} \mathrm{m}^{-2} \mathrm{~s}^{-1}$. Yellow regions of the variegated leaves recorded very low photosynthetic rate compared to greener portion of variegated leaves and wild type leaves. 
Similarly, in both the varieties stomatal conductance of green region of variegated leaves and the normal leaves are higher than yellow regions of the variegated leaves, so is the transpiration rate. Stomatal conductance of green region of variegated leaves and the normal leaves is $0.1867 \mathrm{~mole}^{-2} \mathrm{~s}^{-1}$ and 0.2228 mole $\mathrm{m}^{-2} \mathrm{~s}^{-1}$ respectively in Mangala variety and in S.K. Local the values were $0.1170 \mathrm{~mole} \mathrm{~m}^{-2} \mathrm{~s}^{-1}$ and 0.1050 mole $\mathrm{m}^{-2} \mathrm{~s}^{-1}$ respectively. Stomatal conductance of yellow regions of the variegated leaves in Mangala and S.K. Local varieties is $0.1028 \mathrm{~mole} \mathrm{~m}^{-2} \mathrm{~s}^{-1}$ and $0.0683 \mathrm{~mole} \mathrm{~m}^{-2} \mathrm{~s}^{-1}$ respectively. Greener portion of variegated leaves and the normal leaves showed higher values for transpiration than yellow regions of the variegated leaves in both the varieties. In Mangala variety transpiration rate is $3.7478 \mathrm{~m} \mathrm{~mole} \mathrm{~m}^{-2} \mathrm{~s}^{-1}$ for green region of variegated leaves and $3.8307 \mathrm{~m} \mathrm{~mole} \mathrm{~m}^{-2} \mathrm{~s}^{-1}$ for wild type leaves and in S.K.

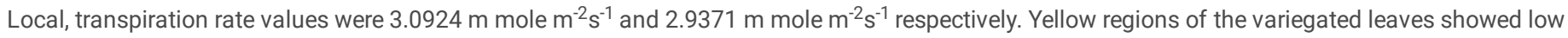
transpiration rate in Mangala (2.3482 $\mathrm{m} \mathrm{mole} \mathrm{m}^{-2} \mathrm{~s}^{-1}$ ) and S.K. Local (1.9983 $\left.\mathrm{m} \mathrm{mole} \mathrm{m}^{-2} \mathrm{~s}^{-1}\right)$ varieties.

Expectedly, stomatal resistance was low in green region of variegated leaves and normal leaves compared to yellow regions. In Mangala, stomatal resistance of green regions of variegated leaves, normal leaves and yellow regions of the variegated leaves is $1.4067 \mathrm{~s} \mathrm{~cm}^{-1}, 1.7833 \mathrm{~s} \mathrm{~cm}-1$ and $8.3667 \mathrm{~s} \mathrm{~cm}{ }^{-1}$ respectively. In S.K. Local, stomatal resistance of green regions of variegated leaves, normal leaves and yellow regions of the variegated leaves is $5.0333 \mathrm{~s} \mathrm{~cm}^{-}$ $1,1.7833 \mathrm{~s} \mathrm{~cm}^{-1}$ and $10.8667 \mathrm{~s} \mathrm{~cm}^{-1}$ respectively. Yellow regions of the variegated leaves showed very low chlorophyll index compared to green region of variegated leaves and normal leaves in both the varieties. Chlorophyll index of yellow regions of the variegated leaves, green region of variegated leaves and normal leaves in Mangala variety is $16.7667,54.2667$ and 67.00 respectively and in S.K. Local variety the chlorophyll index values were $22.8333,59.6667$ and 66.2000 respectively.

The photosynthetic rate of greener portion of variegated leaves did not differ significantly from the wild type leaves. Yellow regions of the variegated leaves showed very low chlorophyll index measurements compared to greener regions or normal leaves, hence yellow regions showed lower photosynthetic rate. Similarly stomatal conductance of green regions of variegated leaves and the normal leaves are higher than yellow regions of the variegated leaves so is the transpiration rate. Hence, expectedly, stomatal resistance was low in green regions of variegated leaves and normal leaves. Variegations in the leaves and consequently the yellow regions with less chlorophyll content reduced the transpiration rate because of its stomatal resistance but low chlorophyll content markedly influenced photosynthetic rate too.

\section{Variation in biochemical constituents}

Biochemical constituents like total sugar, total phenolics and non-tannin phenolics and antioxidant potential in terms of reducing power using CUPRAC and FRAP methods were analyzed along with moisture content in both immature and ripened arecanut of both normal and variegated types of Mangala and South Kanara Local varieties, and the results are given in Table 3 and 4 . The results indicated that there is a wide variation between normal and variegated types for all the biochemical constituents studied. Moisture content at immature stage was about 76.95 to $80.88 \%$ and both normal and variegated types of Mangala and South Kanara Local varieties not shown any significant difference, while at ripened stage, variegated nuts of Mangala variety had significantly high amount of moisture (47.5\%) than the normal nuts (39.5\%), but in the case of South Kanara Local not much variation was observed for moisture content between variegated (33.95\%) and normal (36.3\%) ripened nuts.

Immature arecanut of Mangala variety had high amount of total sugar (66.47g) than the variegated arecanut (44.5g), but in case of South Kanara Local variegated nuts recorded more total sugar content $(32.2 \mathrm{~g})$ than the normal nuts $(24.32 \mathrm{~g})$. Sugar content in the ripened arecanut of normal $(13.59 \mathrm{~g})$ and variegated $(13.83 \mathrm{~g})$ nuts of Mangala variety did not show any significant differences, but in the case of South Kanara Local, ripened normal nuts had significantly high amount of total sugar $(17.72 \mathrm{~g})$ than variegated nuts $(15.18 \mathrm{~g})$. Total phenolic content in immature normal nut of Mangala variety was significantly high $(45.75 \mathrm{~g})$ than the variegated nuts $(24.69 \mathrm{~g})$, but in case of South Kanara Local, variegated nuts recorded high amount of phenolics (41.0g) than the normal nuts $(32.8 \mathrm{~g})$. At matured stage, normal and variegated nuts of both Mangala and South Kanara Local not shown any significant difference and the content was ranged between 14.93 to $16.53 \mathrm{~g}$.

Non-tannin phenol content also varied significantly in immature nuts of Mangala variety. Normal nuts had more non-tannin phenolics (3.27g) than variegated nuts $(0.38 \mathrm{~g})$. Compared to Mangala variety, South Kanara Local recorded high amount of non-tannin phenolics (12.0-15.8 g), and variegated nuts had significantly high amount (15.8g) than the normal nuts $(12.0 \mathrm{~g})$. The non-tannin phenolic content in the matured Mangala variety was about $0.92-0.94 \mathrm{~g}$ and no significant differences observed between variegated and normal nuts. In the case of South Kanara Local, normal nuts recorded higher amount of nontannin phenolics $(7.32 \mathrm{~g})$ than the variegated nuts $(4.66 \mathrm{~g})$. The results indicated that the Mangala variety had high amount of tannins than the South Kanara Local, and the differences was high for immature nuts than the ripened nuts.

Similar type of trend was observed for antioxidant potential in terms of reducing power measured by both FRAP and CUPRAC methods. Since total phenolic content is the major secondary metabolite responsible for the antioxidant potential, arecanut samples with more phenolic content showed better antioxidant potential. Mostly the antioxidant potential measured by CUPRAC was found higher than the values obtained by FRAP method. Immature nuts of both Mangala and South Kanara Local had significantly high amount of antioxidant potential measured by CUPRAC method and this could be due to the presence of high amount of total phenolics. Normal immature nuts of Mangala variety showed significantly high amount of antioxidant potential (1046 mM TE) than the variegated arecanut ( $630 \mathrm{mM} \mathrm{TE}$ ), and in the case of South Kanara Local variegated nuts had high amount of antioxidant potential (1580 mM TE) than the normal nuts (1210 mM TE). In case of ripened nuts, no significant difference was observed between normal and variegated nuts of both Mangala and South Kanara Local and South Kanara Local had slightly high level of antioxidant potential. Antioxidant potential measured by FRAP method was also showed similar trend and it was comparatively less in South Kanara Local than Mangala variety irrespective of the types and maturation stages. Significant variation was observed only between variegated and normal immature nuts of Mangala variety.

\section{Declarations}


Authors are grateful to Indian Council of Agricultural Research (ICAR), Ministry of Agriculture and Farmers Welfare, Govt. of India, New Delhi for funding. Our gratitude to Mr. Annapoorna Prasad Rai, Farmer, Palthady, Puttur Tk., Dakshina Kannada Dt., Karnataka and Mr. Anil Balanja, Farmer, Gardady, Belthangady Tk., Dakshina Kannada Dt., Karnataka for their cooperation in carrying out this study.

\section{Conflicts of interest/Competing interests}

There are no conflicts of interest

Availability of data and material: NA

Code availability: NA

\section{References}

Apak R, Güçlü K, Özyürek M, Karademir SE (2004) Novel total antioxidant capacity index for dietary polyphenols and vitamins C and E, using their cupric ion reducing capability in the presence of neocuproine: CUPRAC method. Journal of Agricultural and Food Chemistry. 52(26): $7970-7981$.

Bavappa KVA (1966) Morphological and anatomical studies in Areca catechu L. and Areca triandra R. Phytomorphology 16: $436-443$.

Benzie IEF, Strain JJ (1996) The ferric reducing ability of plasma (FRAP) as a measure of "antioxidant power": The FRAP assay. Analytical

biochemistry 239(1): 70-76.

DuBois KM, Gilles KA, Hamilton JK, Rebers PT, Smith F (1956) Colorimetric method for determination of sugars and related substances. Analytical Chemistry 28(3): 350-356.

Kher MA (1961). Studies on variegated mango. South Indian Horticulture 9: 13-19.

Kirk JTO, Tilney-Bassett RAE (1978) The Plastids- Their chemistry, structure, growth and inheritance. Elsevier/North-Holland Biomedical Press, Amsterdam.

M'bo Kacou Antoine Alban, Apshara ES. Hebbar KB, Tahi GM (2015) Morpho-physiological criteria for assessment of two month old cocoa genotypes for drought tolerance. Indian Journal of Plant Physiology 21(1): 23-30.

Marcotrigiago M (1997) Chimeras and variegation: patterns of deceit. Hort science 32(5): 773-784.

Singleton VL, Orthofer R, Lamuela-Raventós RM, (1999) Analysis of total phenols and other oxidation substrates and antioxidants by means of folin-ciocalteu reagent. Methods in Enzymology 299: 265-275.

Somogyi M (1952) Determination of reducing sugars by Nelson-Somogyi method. Journal of Biological Chemistry 200: 245.

Tsai CC, Wu YJ, Sheue CR, Liao PC, Chen YH, Li SJ, et al. (2017) Molecular basis underlying leaf variegation of a Moth Orchid Mutant (Phalaenopsis aphrodite subsp. formosana). Frontiers in Plant Science 8: 1-11. DOI=10.3389/fpls.2017.01333.

\section{Tables}

Table 1. Morphological traits of normal and variegated arecanut trees of Mangala and South Kanara Local varieties

\begin{tabular}{|c|c|c|c|c|c|c|c|c|c|c|c|c|c|c|}
\hline Varieties & Type & $\begin{array}{l}\text { Plant } \\
\text { Ht. } \\
\text { (m) }\end{array}$ & $\begin{array}{l}\text { Stem } \\
\mathrm{Ht} . \\
(\mathrm{m})\end{array}$ & $\begin{array}{l}\text { Crown } \\
\text { Length } \\
(\mathrm{m})\end{array}$ & $\begin{array}{l}\text { Stem } \\
\text { Girth } \\
\text { (cm) }\end{array}$ & $\begin{array}{l}\text { Internodal } \\
\text { Length } \\
\text { (cm) }\end{array}$ & $\begin{array}{l}\text { No. of } \\
\text { Leaves }\end{array}$ & $\begin{array}{l}\text { Leaf } \\
\text { Length } \\
\text { (cm) }\end{array}$ & $\begin{array}{l}\text { Leaf } \\
\text { Breadth } \\
\text { (cm) }\end{array}$ & $\begin{array}{l}\text { No. of } \\
\text { Leaflets } \\
\text { (Left) }\end{array}$ & $\begin{array}{l}\text { No. of } \\
\text { Leaflets } \\
\text { (Right) }\end{array}$ & $\begin{array}{l}\text { No. of } \\
\text { Midribs } \\
\text { (Left) }\end{array}$ & $\begin{array}{l}\text { No. of } \\
\text { Midribs } \\
\text { (Right) }\end{array}$ & $\begin{array}{l}\text { Lc } \\
\text { Le } \\
\text { Le }\end{array}$ \\
\hline \multirow[t]{2}{*}{ Mangala } & Variegated & 11.02 & 9.17 & 1.85 & 48 & 12.9 & 10 & 157 & 162 & 35 & 41 & 63 & 61 & 62 \\
\hline & Normal & 9.09 & 7.13 & 1.96 & 50 & 14.15 & 11 & 160 & 180 & 43 & 38 & 69 & 67 & 78 \\
\hline \multirow{2}{*}{$\begin{array}{l}\text { S.K. } \\
\text { Local }\end{array}$} & Variegated & 9.42 & 8.40 & 1.02 & 44 & 10.83 & 11 & 195 & 145 & 37 & 38 & 65 & 68 & 68 \\
\hline & Normal & 11.67 & 10.76 & 0.91 & 54 & 14.19 & 10 & 140 & 155 & 43 & 44 & 67 & 68 & 78 \\
\hline
\end{tabular}

Table 2. Physiological measurements of variegated and normal arecanut leaves of Mangala and S. K. Local varieties 


\begin{tabular}{|c|c|c|c|c|c|c|c|c|c|}
\hline & \multicolumn{5}{|c|}{ Variegated arecanut of Mangala variety } & \multicolumn{4}{|c|}{ Variegated arecanut of S.K. Local variety } \\
\hline & Photosynthesis & Conductance & Transpiration & $\begin{array}{l}\text { Stomatal } \\
\text { resistance }\end{array}$ & $\begin{array}{l}\text { chlorophyll } \\
\text { index }\end{array}$ & Photosynthesis & Conductance & Transpiration & $\begin{array}{l}\text { Stomatal } \\
\text { resistanc }\end{array}$ \\
\hline & $\begin{array}{l}\mu \text { mole } \\
\mathrm{m}^{-2} \mathrm{~s}^{-1}\end{array}$ & $\begin{array}{l}\text { mole } \\
\mathrm{m}^{-2} \mathrm{~s}^{-1}\end{array}$ & $\mathrm{~m}_{1} \mathrm{~mole}^{-2} \mathrm{~s}^{-}$ & $\mathrm{s} \mathrm{cm-1}$ & & $\begin{array}{l}\boldsymbol{\mu} \text { mole } \\
\mathrm{m}^{-2} \mathrm{~s}^{-1}\end{array}$ & $\begin{array}{l}\text { mole } \\
\mathrm{m}^{-2} \mathrm{~s}^{-1}\end{array}$ & $\begin{array}{l}\mathrm{m} \text { mole } \\
\mathrm{m}^{-2} \mathrm{~s}^{-1}\end{array}$ & $\mathrm{~s} \mathrm{~cm}-1$ \\
\hline $\begin{array}{l}\text { Variegated } \\
\text { green } \\
\text { (Mean } \\
\text { values) }\end{array}$ & $4.4104^{\mathrm{A}}$ & $0.1867^{A}$ & 3.7478 & $1.4067^{B}$ & $54.2667^{\mathrm{A}}$ & $3.7080^{A}$ & 0.1170 & 3.0924 & $5.0333^{B}$ \\
\hline $\begin{array}{l}\text { Variegated } \\
\text { yellow } \\
\text { (Mean } \\
\text { values) }\end{array}$ & $1.1966^{\mathrm{B}}$ & $0.1028^{B}$ & 2.3482 & $8.3667^{A}$ & $16.7667^{\mathrm{B}}$ & $1.7332^{\mathrm{B}}$ & 0.0683 & 1.9983 & $10.8667^{A}$ \\
\hline $\begin{array}{l}\text { Control } \\
\text { leaves } \\
\text { (Mean } \\
\text { Values) }\end{array}$ & $3.4348^{\mathrm{A}}$ & $0.2228^{A}$ & 3.8307 & $1.7833^{\mathrm{B}}$ & $67.00^{A}$ & $3.8569^{A}$ & 0.1050 & 2.9371 & $1.7833^{C}$ \\
\hline p-value & 0.0056 & 0.0003 & 0.2856 & 0.0105 & 0.0003 & 0.0084 & 0.3277 & 0.2958 & 0.0003 \\
\hline $\mathrm{CD}$ at $5 \%$ & 1.4422 & 0.0777 & 2.1819 & 3.9083 & 13.4838 & 1.1283 & 0.0705 & 1.5775 & 2.2574 \\
\hline $\begin{array}{l}\text { Mean } \\
\text { Squared } \\
\text { Error }\end{array}$ & 0.5847 & 0.0017 & 1.3383 & 4.294 & 51.1089 & 0.3579 & 0.0014 & 0.6996 & 1.4325 \\
\hline
\end{tabular}

Table 3. Biochemical composition of normal and variegated arecanut samples of Mangala variety (per $100 \mathrm{~g}$ )

\begin{tabular}{|c|c|c|c|c|c|c|}
\hline \multirow[t]{2}{*}{ Sample ID } & \multirow[t]{2}{*}{ Moisture \% } & \multirow[t]{2}{*}{ Total sugar } & \multirow[t]{2}{*}{ Total phenolic content ( $\mathrm{g}$ GAE) } & \multirow{2}{*}{$\begin{array}{l}\text { Non-Tannin } \\
\text { phenolic content } \\
\text { (g GAE) }\end{array}$} & \multicolumn{2}{|c|}{ Antioxidant capacity (mM TE) } \\
\hline & & & & & CUPRAC & FRAP \\
\hline \multicolumn{7}{|l|}{ Immature Nuts } \\
\hline Variegated & 79.0 & $44.5000^{\mathrm{B}}$ & $24.6900^{\mathrm{B}}$ & $0.3800^{\mathrm{B}}$ & $629.5700^{\mathrm{B}}$ & $213.9600^{\mathrm{B}}$ \\
\hline Normal & 78.0 & $66.4700^{\mathrm{A}}$ & $45.7500^{\mathrm{A}}$ & $3.2700^{A}$ & $1046.1900^{A}$ & $371.1600^{A}$ \\
\hline p-value & & 0.0022 & 0.0003 & $<.0001$ & 0.0001 & 0.0003 \\
\hline $\mathrm{CD}$ at $5 \%$ & & 8.0589 & 4.4201 & 0.2775 & 74.9395 & 35.4851 \\
\hline Mean Squared Error & & 14.7497 & 4.437 & 0.0175 & 1275.4034 & 285.9677 \\
\hline \multicolumn{7}{|l|}{ Ripened Nuts } \\
\hline Variegated & 47.5 & 13.83 & 14.93 & 0.92 & 289.25 & 277.35 \\
\hline Normal & 39.5 & 13.59 & 15.12 & 0.94 & 284.9 & 292 \\
\hline p-value & & 0.7205 & 0.6672 & 0.9645 & 0.5335 & 0.2636 \\
\hline $\mathrm{CD}$ at $5 \%$ & & 1.6059 & 1.0540 & 1.0869 & 16.4278 & 28.9708 \\
\hline Mean Squared Error & & 0.5857 & 0.2523 & 0.2683 & 61.2894 & 190.6101 \\
\hline
\end{tabular}

Except moisture all values are calculated on dry weight basis, and results are given for $100 \mathrm{~g}$ of sample;

GAE- Gallic acid Equivalent; TE- Trolox Equivalent

Table 4. Biochemical composition of normal and variegated arecanut samples of South Kanara Local variety (per $100 \mathrm{~g}$ ) 


\begin{tabular}{|c|c|c|c|c|c|c|}
\hline \multirow[t]{2}{*}{ Sample ID } & \multirow[t]{2}{*}{ Moisture \% } & \multirow[t]{2}{*}{ Total sugar $\%$} & \multirow{2}{*}{$\begin{array}{l}\text { Total phenolic content } \\
\text { (g GAE) }\end{array}$} & \multirow{2}{*}{$\begin{array}{l}\text { Non-Tannin phenolic content } \\
\text { (g GAE) }\end{array}$} & \multicolumn{2}{|c|}{ Antioxidant capacity (M TE) } \\
\hline & & & & & CUPRAC & FRAP \\
\hline \multicolumn{7}{|l|}{ Immature Nuts } \\
\hline Variegated & 80.88 & $27.7400^{\mathrm{B}}$ & $41.0400^{\mathrm{A}}$ & $15.3700^{A}$ & $1.4700^{\mathrm{B}}$ & 0.134 \\
\hline Variegated & 80.12 & $32.2000^{A}$ & $41.0300^{\mathrm{A}}$ & $15.8400^{\mathrm{A}}$ & $1.5800^{\mathrm{A}}$ & 0.151 \\
\hline Normal & 77.42 & $24.8900^{\mathrm{BC}}$ & $32.2400^{\mathrm{B}}$ & $12.0200^{\mathrm{B}}$ & $1.1200^{\mathrm{C}}$ & 0.109 \\
\hline Normal & 76.95 & $24.3200^{C}$ & $32.8000^{\mathrm{B}}$ & $12.6400^{\mathrm{B}}$ & $1.2100^{\mathrm{C}}$ & 0.114 \\
\hline $\mathrm{p}$-value & 0.3484 & 0.0013 & 0.0033 & $<.0001$ & $<.0001$ & 0.1879 \\
\hline CD at $5 \%$ & 5.4281 & 2.9414 & 4.6699 & 0.8997 & 0.0906 & 0.0444 \\
\hline Mean Squared Error & 8.9678 & 2.6333 & 6.6375 & 0.2464 & 0.0025 & 0.0006 \\
\hline \multicolumn{7}{|l|}{ Ripened Nuts } \\
\hline Variegated & 35.81 & $14.3300^{\mathrm{B}}$ & 14.94 & $4.1700^{C}$ & 0.299 & 0.123 \\
\hline Variegated & 33.95 & $15.1800^{B}$ & 14.99 & $4.6600^{C}$ & 0.302 & 0.123 \\
\hline Normal & 36.19 & $17.5900^{\mathrm{A}}$ & 16.03 & $5.4900^{\mathrm{B}}$ & 0.318 & 0.136 \\
\hline Normal & 36.3 & $17.7200^{\mathrm{A}}$ & 16.53 & $7.3200^{A}$ & 0.356 & 0.146 \\
\hline $\mathrm{p}$-value & 0.1697 & 0.0015 & 0.2704 & $<.0001$ & 0.1426 & 0.1424 \\
\hline CD at $5 \%$ & 2.33526 & 1.4313 & 1.9693 & 0.5416 & 0.0543 & 0.0256 \\
\hline Mean Squared Error & 1.6598 & 0.6236 & 1.1804 & 0.0893 & 0.0009 & 0.0002 \\
\hline
\end{tabular}

Except moisture all values are calculated on dry weight basis, and results are given for $100 \mathrm{~g}$ of sample;

GAE- Gallic acid Equivalent; TE-Trolox Equivalent

\section{Figures}




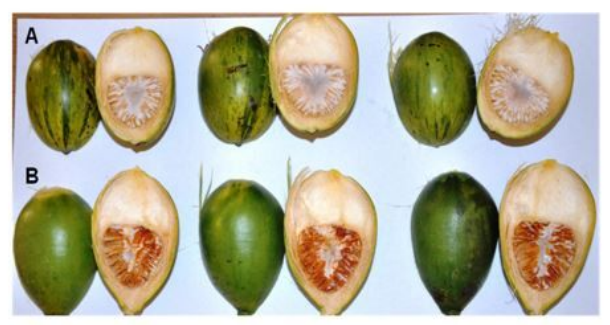

Immature nuts - A: Variegated arecanut; B: Normal arecanut

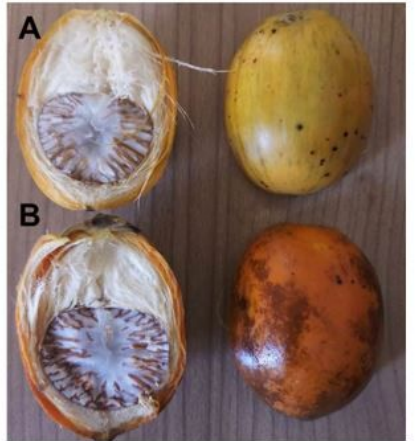

Ripened nuts - A: Variegated arecanut; B: Normal arecanut

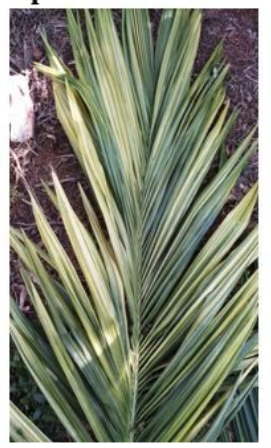

A: Variegated arecanut leaf

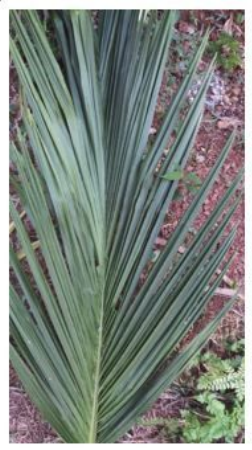

B: Normal arecanut leaf

Figure 1

Variegated and normal arecanut of Mangala variety 


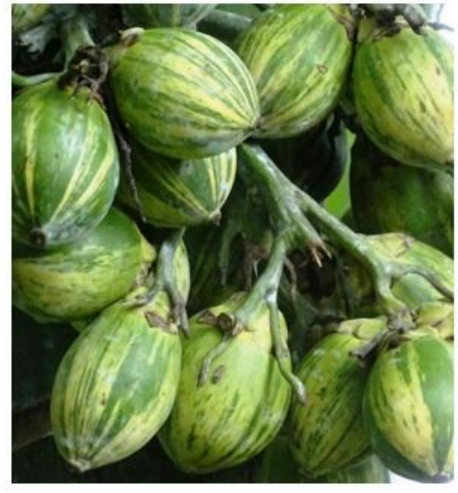

Immature nuts

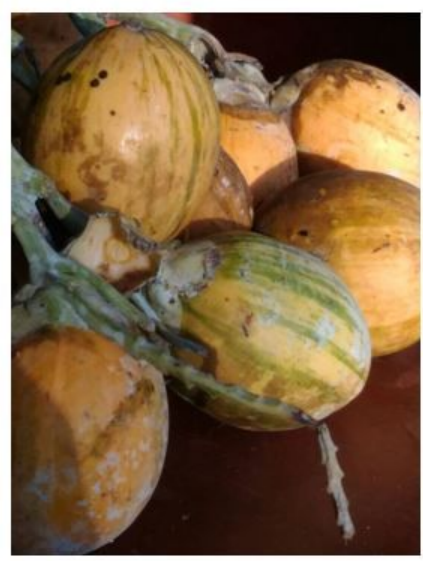

Ripened nuts

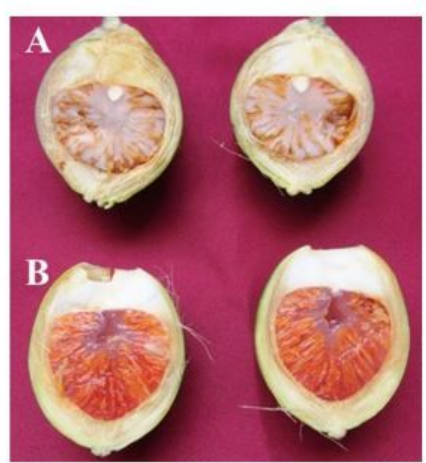

A: Normal arecanut; B: Variegated arecanut

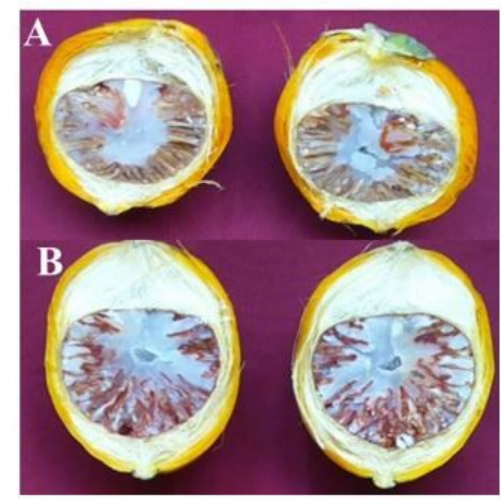

A: Normal arecanut; B: Variegated arecanut

Figure 2

Variegated and normal arecanut of South Kanara Local variety 